\title{
RELATIONSHIP BEHAVIOR OF STUDENTS ON THE MAINTENANCE OF ORAL HEALTH TOWARDS CARIES RISK IN CLASS VII MTSN 2 PONTIANAK CITY
}

\author{
Asnya , Endah Aryati b \\ a) Poltekkes Kemenkes Pontianak \\ b) Poltekkes Kemenkes Semarang
}

\begin{abstract}
Behavior is one of the factors that affect oral health can affect the dental health status of individuals or society. The behavior may also influence the risk of caries. The purpose of this research is to know there is a Student Behavior Relationships On Dental and Oral Health Care Score Against Caries In Seventh Grade Students MTSN 2 Pontianak. Type of research is descriptive correlation method with cross sectional study design. Sample namely Seventh Grade Students MTSN 2 Pontianak totaling 83 sampling purposive sampling technique. Data was analyzed using univariate and bivariate analysis of the research data was analyzed statistically by Fisher Exact Test. Results of student behavior research on dental and oral health care to the DMFT figures show knowledge $(p=0.000)$, physics $(p=0.000)$, Action $(p=0.000)$. It can be concluded that there is a relationship of student behavior on the maintenance of oral health to the number of caries in class VII MTSN 2 Pontianak. Suggestion given is the existence of social interaction which can affect changes in dental health care measures
\end{abstract}

Keywords: Behavior, Dental Caries index (DMFT)

\section{Introduction}

Dental and oral health conditions are volatile which is influenced by bioliogical, psychological, spiritual conditions, as well as developmental factors for oral health and general health. These conditions are interconnected and influence each other. Some problems that occur in the mouth and teeth occur due to lack of maintaining oral and dental hygiene. This is related to the occurrence of plaque buildup on the tooth surface. Plaque accumulation is the beginning of several diseases in the oral cavity including caries and periodontal disease. (Alaluusua, et al, 1994)

According to the dental and oral health profile listed in the Basic Health Research (RISKESDAS) in 2013, the national prevalence of Active Caries was $43.4 \%$. Data shows that

*) Corresponding Author (Asny)

E-mail: asnywahab@yahoo.co.id
Indonesian people are still on has a high caries prevalence rate. A total of 14 provinces have an Active Caries prevalence above the national prevalence, namely Riau, Jambi, South Sumatra, Bangka Belitung, In Yogyakarta, East Java, West Kalimantan, Central Kalimantan, South Kalimantan, East Kalimantan, North Sulawesi, Central Sulawesi, Southeast Sulawesi, and Maluku.

The process of caries involves oral bacteria which also accumulates in plaque. This bacterium will decompose the substrate and the results of this bacterial metabolism will cause acidity conditions $(\mathrm{pH})$ to increase. This condition continues to cause decalcification of enamel, and form white spot lesions that indicate the start of the caries process.

Hard tooth tissue can be damaged due to acidic substances; The damage that occurs is called caries. This happens because the carbohydrate fermentation process is carried out 
by oral bacteria that produce acidic substances.(RISKESDAS, 2013)

The mechanism of caries occurrence is related to the process of demineralization and remineralization. Plaque on the tooth surface consists of bacteria that produce acid as a result of its metabolism. This acid will then dissolve calcium phosphate minerals in tooth enamel or dentin in a process called demineralization. If this process cannot be stopped, cavities will form on the tooth surface, namely caries. (Alaluusua, et al, 1994) As research develops, several factors that influence caries occurrence include physical, biological, environmental, behavioral, and lifestyle risk factors. ${ }^{4}$ Behavior is a major factor causing caries in developing countries.

Dental structures that suffer from caries or damage that require additional recovery and maintenance throughout life. The treatment carried out is also not an easy treatment. The condition of caries-free permanent teeth at the age of 12 years is not easy to find because of the condition of small caries that is not done properly treatment it will expand, where the severity of the disease increases with age. (Axelsson, et al, 1974)

Eating patterns, which are carried out and maintenance efforts on teeth and mouth are some of the behaviors that affect caries. Diet includes the frequency of meals, time and type of food.(Axelsson, et al, 1974) The frequency of eating in children is very varied and they really like to eat snacks between meals, this is what causes a lot of plaque buildup because the process of demineralization continues to occur before the body can make the process of remineralization.(Hariyani, et al, 2019)

The World Health Organization (WHO, 2003) recommends conducting examinations dental in the 12-age group year, because it is an age group that is critical of dental health, it is estimated that children aged 12-15 years who have just left elementary school, so it is expected that children can adopt behaviors about maintenance dental and oral health obtained from elementary school at the level of SMP / MTSN.

Based on preliminary data obtained from the results of health screening conducted by the Karya Mulia Health Center, Sungai Bangkong Subdistrict, Pontianak Kota District on grade VII students conducted in August 2018, it was obtained that from 415 students examined, 215 students had caries, which resulted in students often complain of toothache when at school it disrupts teaching and learning activities, for behavior about oral health is also still lacking. Based on the information above, the author is interested in conducting research on "The Relationship of Student Behavior About the Maintenance of Oral and Dental Health Against Caries Risk in Class VII Students of MTSN 2 Pontianak City".

\section{Method}

The research method used is descriptive correlation. Descriptive research method is a method of research carried out with the aim to make a picture of a situation objectively. Descriptive correlation method is research performed using a relationship between two variables or more.

The research design used was cross sectional, where each respondent was only observed once and the measurement of the respondent's variables at the time of the examination, then the study was not followed up (Riyanto, 2011). With the Statistical Test was Fisher Exact Test.

\section{Result and Discussion}

The sample in this study amounted to 83 children, consisting of 40 boys $(48.2 \%)$ and 43 girls $(51.8 \%)$. The average education level of parents is as follows D3 (20.5\%) and S1, S2 (79.5\%).

Bivariate analysis was carried out to identify whether there was a relationship between the independent variable (behavior about maintaining oral health) and the dependent variable (caries risk). Caries risk is defined as the number of caries and categorized in 3 categories: low (under 3), moderate (3-4), high (above 4)

The statistical test used was the Fisher Exact test. The study was conducted by examining caries risk by examining the caries risk of the respondents and the distribution of questionnaires covering knowledge, attitudes and actions.

The results of the data obtained from the questionnaire include knowledge, attitudes and actions presented in the following table 1 .. 
a. Student Knowledge of Caries

Table 1. Results of Fisher Exact analysis of knowledge with caries risk on MTSN 2 Students Pontianak City

\begin{tabular}{lccccc}
\hline \multicolumn{1}{c}{ Caries } & low & moderate & high & \multirow{2}{*}{ total } & \multirow{2}{*}{ P value } \\
\cline { 1 - 4 } Knowledge & $\mathbf{n}$ & $\mathbf{n}$ & $\mathbf{n}$ & & \\
\hline Good & 31 & 11 & 0 & 42 & 0.000 \\
Average & 0 & 21 & 8 & 29 & \\
Lack & 0 & 0 & 12 & 12 & \\
Total & 31 & 32 & 20 & 83 & \\
\hline
\end{tabular}

Based on the table above ( table 1 ), it can be concluded that the tendency of students to have good knowledge and caries risk is a low category of 31 students and there are students who have medium category knowledge with high karis of 8 students.
Can be seen in the Fisher Exact Test shows that the value of $0,000(<0.05)$ which means there is a significant relationship between knowledge of caries in MTSN 2 Students Pontianak City.

b. Students 'Attitudes Toward Caries

Table 2. Results of Fisher Exact analysis of Attitudes with caries risk on MTSN 2 Students Pontianak City

\begin{tabular}{|c|c|c|c|c|c|}
\hline Caries & low & moderate & high & total & \multirow{2}{*}{$\begin{array}{l}\mathrm{P} \\
\text { value }\end{array}$} \\
\hline Attitudes & $\mathrm{n}$ & $\mathrm{n}$ & $\mathrm{n}$ & & \\
\hline Good & 13 & 1 & 0 & 14 & \multirow{4}{*}{0.000} \\
\hline Average & 16 & 11 & 0 & 27 & \\
\hline Lack & 6 & 21 & 15 & 42 & \\
\hline Total & 35 & 32 & 16 & 83 & \\
\hline
\end{tabular}

Based on the above table (table 2) it appears that the attitude tendency of MTSN 2 Students in Pontianak City has a bad attitude with the risk of caries categorized as medium (21 children) and it is seen that in students who have a bad attitude but have good caries categories by 6 students. Can be seen in

c) Student Actions of Caries the Fisher Exact Test shows that the value is $0,000(<0.05)$ which means there is a significant relationship between attitudes towards caries in MTSN 2 Students Pontianak City.

Table 3 Results of Fisher Exact analysis of Actions with caries risk on MTSN 2 Students Pontianak City

\begin{tabular}{|c|c|c|c|c|c|}
\hline Caries & low & moderate & high & total & $\mathrm{P}$ value \\
\hline Action & $\mathrm{n}$ & $\mathrm{n}$ & $\mathrm{n}$ & & \\
\hline Good & 8 & 0 & 0 & 8 & \multirow{4}{*}{0.000} \\
\hline Average & 21 & 10 & 0 & 31 & \\
\hline Lack & 2 & 22 & 20 & 44 & \\
\hline Total & 23 & 32 & 20 & 83 & \\
\hline
\end{tabular}

Based on table 3 above there is a tendency for actions to take care of poor dental health so that it has a moderate caries risk (22 students) and is almost balanced with the number of students who have bad actions with high caries which is as many as 20 students. While there are only 8 students who have good dental maintenance measures so the risk of caries is low. Can be seen in the Fisher Exact Test shows that the value of $0,000(<0.05)$ which means there is a significant relationship between the action of caries in students MTSN 2 Pontianak City.

The results of the analysis of the relationship of dental health maintenance knowledge with caries risk in school children in MTSN 2 Pontianak city showed a p-value of 0,000 which means that there is a significant relationship between knowledge of dental 
maintenance on the emergence of dental caries. This is because the average respondent is a student who has a good environment so that students can easily get sources of knowledge from several sources, especially those related to maintaining high dental health. There are some respondents who have caries, this is related to the lack of understanding of the correct chewing function of soft foods, because the interview results of these respondents tend to like soft foods. It is known that there is a relationship between knowledge and one's behavior. Where human knowledge is obtained through education, the experience of others, the mass media and the environment.(WHO, 2003) These results are in line with other studies that show that there is a significant relationship between dental and oral health knowledge with theDMF-T index, which is carried out on grade XII students at YP High School Antasari Deli Serdang.(Monang, 2018)

Dental health maintenance behavior of attitudes can affect the caries risk because it is understood as a result of the formation of knowledge and attitude domains. Influence on the formation and appreciation of changes in social stimulation, one of which is influenced by personal experience, what has been and is being experienced by someone. The response will be one of the basic forms of attitude. In order to have a response and appreciation, a person must have experience related to psychological objects. Furthermore, that appreciation will then form a positive attitude or a negative attitude, will depend on various other factors.

This is also evident from the results of the analysis of the relationship of attitudes and actions for maintaining dental health with caries rates in school children in MTSN 2 Pontianak city showing a $p$-value of 0,000 which means that there is a significant relationship between attitudes and actions for dental maintenance on the emergence of dental caries. In the MTSN is one of the schools including schools that have adequate facilities and attention from the internal environment. Character building is always done in the school and family environment. Monitoring is sufficient between the school and the family so that this supports the formation of positive attitudes and actions teeth maintenance that affects the number of caries that arise.

Attitude factor is a factor that contributes to the formation of behavior.(Zuchdi, 1995) Factors that shape attitudes include the influence and presence of others. A person or individual tends to have an attitude that is confirmed or in line with the attitude of people who are considered important. In this study, family factors can be considered as people who have a role in shaping the attitudes and actions of respondents.

Based on this, the formation of knowledge, attitudes and actions to maintain dental health to prevent high caries numbers need the participation of outsiders in adolescents.

\section{Conclusion and Sugestion}

From the results of the study it can be concluded that the behavioral factors of maintaining oral health of Elementary school students still need attention given to the factors of knowledge, attitudes and actions. Significant relationship between dental health maintenance behavior and caries risk shows that good behavior has a low caries risk as well as bad behavior has a high caries risk. There are social interaction factors that have not been measured in this study, therefore in future studies it is recommended to examine family interaction factors including the type of role models of the family in maintaining attitudes and actions avoiding the risk of caries.

\section{Acknowledgements}

I thank Health Officers of Poltekkes Kemenkes Pontianak and Health Scool of MTS 2 of Pontianak who have supported and assisted in carrying out this research so that this research can be completed well and hopefully this research can be useful for readers.

\section{References}

Alaluusua S, Malmivirta R. Early plaque accumulation - a sign for caries risk in young children. Community Dent Oral Epidemiol. 1994;22(5PT1):273-276. doi:10.1111/j.1600-0528.1994.tb0204 9. $x$

National Institute for Health Research \& Development. Riset Kesehatan Dasar (National Health Survey). Minist Heal Repub Indones. 2013;(1):1-303. doi:10.1007/s13398-014-0173-7.2

Yadav K, Prakash S. A Review of Dental Caries. Asian J Biomed Pharm Sci. 
2016;(August):73-80.

doi:10.15272/ajbps.v6i53.773

Petersen PE. Sociobehavioural risk factors in dental caries - International perspectives. Community Dent Oral Epidemiol. 2005;33(4):274-279. doi:10.1111/j.1600-0528.2005.00235.x

Axelsson $\mathrm{P}$, Lindhe J. The effect of a preventive programme on dental plaque, gingivitis and caries in schoolchildren. Results after one and two years. J Clin Periodontol. 1974;1(2):126-138.

doi:10.1111/j.1600-051X.1974.tb0124 8.x

Hariyani N, Soebekti RH, Setyowati D, et al. Factors influencing the severity of dental caries among indonesian children with autism spectrum disorder - A pilot study. Clin Cosmet Investig Dent. 2019;11:227-233. doi:10.2147/CCIDE.S205041

World Health Organization. The World Oral Health Report 2003. Community Dent Oral Epidemiol. 2003;31 Suppl 1:3-23. doi:10.1046/j..2003.com122.x

Monang Panjaitan, Irene Anastasia, Novelina, Pengetahuan Dan Kesehatan Gigi dan Mulut Terhadap Indeks Dmf-T Pada Siswa Kelas XII Di SMA Y . P Antasari Deli Serdang. 2018;1(1).

Zuchdi D. Pembentukan Sikap. J Cakrawala Pendidik. 1995;3(3):51-63. 